\title{
Assessing the Vulnerability of Public-Supply Wells to Contamination: Floridan Aquifer System Near Tampa, Florida
}

The U.S. Geological Survey's National Water-Quality Assessment (NAWQA) Program found, in studies from 1991 to 2001, low levels of mixtures of contaminants in groundwater near the water table in urban areas across the Nation. Contaminants were detected less frequently in deeper groundwater typically developed for public supply (Hamilton and others, 2004). The proximity of contaminant mixtures to underlying public water-supply sources, however, prompted the NAWQA Program to begin intensive studies in 2001 to assess the vulnerability of public-supply wells to contamination. Specifically, pathways and processes by which contaminants reach public-supply wells in nine aquifer systems across the country are being investigated. Scientists are studying the processes that occur below land surface-whereby contaminants are mobilized or attenuated - as well as investigating how human activities can affect the vulnerability of public-supply wells to contamination.

This fact sheet highlights findings from the vulnerability study of a public-supply well in Temple Terrace, Florida (Katz and others, 2007; Crandall and others, in press), northeast of Tampa. The well typically produces water at the rate of 700 gallons per minute from the Upper Floridan aquifer.
In construction and operation, this well is similar to many other public-supply wells in the Tampa Bay region and throughout northern Florida. Historical problems in the public-supply wells of Temple Terrace include high concentrations of total coliform bacteria and fecal streptococci bacteria; however, the current requirement to disinfect all drinking water now protects users of publicly supplied water from health hazards associated with bacterial contamination. Samples collected from the selected public-supply well for the current study contained several types of chemical contaminants including nitrate, volatile organic compounds (VOCs), pesticides, uranium, radon-222,
The aquifer systems near Tampa are composed of sand, clay, and carbonate rocks that were deposited primarily in a marine environment. The uppermost water-bearing unit consists of sand with varying amounts of silt and clay and is referred to as the "surficial aquifer system." Water in this unit originates as rainfall or as lawn irrigation water that infiltrates to the water table. Yields of less than 5 gallons per minute, high iron content, and the potential for contamination make the surficial aquifer system unsuitable for use as a significant source of drinking water. Once infiltrating water reaches the water table, it typically moves downward and laterally through the surficial aquifer system until it reaches the underlying "intermediate confining unit," a clay-rich layer that retards the downward movement of water into lower layers. The thickness of the intermediate confining unit is variable throughout the area, and it contains numerous breaches (called sinkholes) that form when the underlying limestone dissolves, causing the clay layer to collapse. Groundwater can move rapidly downward through these breaches, where it then enters the underlying Upper Floridan aquifer and resumes flow in a primarily lateral direction. The Upper Floridan aquifer is mostly limestone with some layers of dolomite and evaporites. Groundwater in the Upper Floridan aquifer may move slowly through the porous matrix or may travel at a relatively rapid rate through the many fractures and cavities that have been enlarged by dissolution of the limestone. The Upper Floridan aquifer is highly productive and is the principal source of freshwater in west-central Florida. The public-supply well selected for study is open to the Upper Floridan aquifer from 118 to 174 feet below land surface. This zone is tapped by many public-supply wells in the region, although the majority of wells have a longer open interval that extends to a greater depth than that of the selected well. A high-yielding, highly transmissive cavernous zone is intersected near the base of the open interval of the selected public-supply well. This cavernous zone is areally extensive and is noted on logs of many production and monitoring wells throughout the region. 
and arsenic. These contaminants were all detected in untreated water at concentrations less than established drinking-water standards, where such standards exist.

Some of the contaminants detected in the selected public-supply well are anthropogenic (introduced by human activity); others occur naturally. Specifically, elevated concentrations of nitrate and the presence of pesticides are commonly linked with applications of fertilizer and pesticides to golf courses and lawns in urban and residential areas. VOCs are commonly used as solvents or gasoline components. Chloroform is a VOC that can be formed as a byproduct of chlorination. Publicly supplied water containing chloroform may reenter the groundwater system by way of leaking pipes or lawn irrigation. Uranium, radon-222, and arsenic occur naturally in the sediments and rocks that make up the aquifer system in the area.

Overall, the study findings point to four primary factors that affect the movement and fate of contaminants and the vulnerability of the public-supply well in Temple Terrace, Florida: (1) groundwater age (how long ago water entered, or recharged, the aquifer); (2) short-circuiting of contaminated water through sinkholes; (3) natural geochemical processes within the aquifer; and (4) pumping stress. Study findings are intended to help water managers, drinking-water suppliers, and policy-makers to better understand how and why contamination of public-supply wells occurs and whether water quality may improve or degrade. Additionally, study findings may be used to evaluate various pumping, resourcedevelopment, and land-management scenarios.

\section{Well Vulnerability Results from Mixing of Very Recent Recharge with OIder Water}

Groundwater age refers to the elapsed time since water entered or "recharged" an aquifer at the water table. Because water in an aquifer typically flows downward and laterally over time, it is expected that the very youngest water will be found near the water table and older water will be found at greater depths. Groundwater age can be estimated by measuring concentrations of modern age tracers (tritium, its radioactive decay product helium-3, and sulfur hexafluoride). Concentrations of tritium and sulfur hexaflouride increased in the atmosphere - and also in precipitationwithin the last five to six decades as a result of human activities. Thus, groundwater containing these tracers recharged the aquifer within the last 60 years.

In the Temple Terrace area, agetracer data from monitoring wells tapping a surficial aquifer system indicate that most of the water in this aquifer recharged within the past 6 years. In contrast, water samples from monitoring wells in the underlying Upper

\section{Study Design}

A computer model of groundwater flow was constructed at a regional scale to estimate the "zone of contribution" to the selected public-supply well (Crandall, 2007). The zone of contribution is the three-dimensional volume of the aquifer material through which groundwater flows from the time it enters the groundwater system at the water table until it eventually discharges at the selected public-supply well. A network of monitoring wells was installed in or near the simulated zone of contribution to the well to understand groundwater flow and geochemistry along general directions of groundwater flow to the well. Water samples were collected from 28 monitoring wells and the supply well during 2003 through 2005 and analyzed for naturally occurring contaminants (such as uranium and arsenic) and anthropogenic contaminants (such as volatile organic compounds, pesticides, and nutrients). Other water-quality parameters (such as major ions, agedating tracers, and selected stable isotopes) were analyzed for to improve understanding of sources of water and reactions affecting the chemical composition of groundwater. In addition, water samples were collected from the supply well at three depth intervals under nonpumping and pumping conditions to determine where water and contaminants enter the well and to assess the effect of pumping on water quality. Finally, a more detailed, local-scale computer model of groundwater flow to the selected public-supply well was constructed to estimate the traveltime of water particles entering the publicsupply well and to simulate long-term nitrate concentrations reaching the well (Crandall and others, in press).

Floridan aquifer are mixtures of old water (recharged more than 60 years ago) and varying proportions of young water (recharged within the past 6 years). Estimated proportions of young water range from nearly zero for water from the deepest monitoring wells (screened 180 to 300 feet below land surface) to 25 percent for the shallowest monitoring wells in the Upper Floridan aquifer. A few monitoring wells produce water from the cavernous zone (see text box describing aquifer); estimated proportions of young water for these wells is as great as 50 percent.

The selected public-supply well taps the Upper Floridan aquifer and the areally extensive cavernous zone. Age-tracer data suggest that a substantial fraction of young water is produced by the publicsupply well. To better understand the blend of water of different ages (or "age distribution of water") produced by the public-supply well, a computer-model simulation of groundwater flow was used to estimate the traveltime (or age) of water particles entering the public-supply well along the 56-foot length of the open interval. Modeled findings show that the simulated ages of particles reaching the public-supply well range from less than 1 day to about 130 years (fig. 1). Roughly 50 percent of the simulated flow to the well consists of water less than about 10 years old. The youngest water enters the well through the cavernous zone near the base of the open interval in these simulations. The large percentage of young water produced by the public-supply well is noteworthy because young groundwater is vulnerable to contamination from human activities, whereas groundwater older than about 60 years recharged before the use of manmade chemicals became prevalent.

\section{Karst Features Serve as Short Circuits for Movement of Contaminants into the Public Supply Well}

The concentrations of anthropogenic compounds - such as nitrate (fig. 2) and VOCs - and the number of pesticide detections at the wellhead of the publicsupply well are intermediate between those detected in water from monitoring wells in the surficial aquifer system and the Upper Floridan aquifer. Similarly, the public-supply well produces water with concentrations of the natural contaminant 


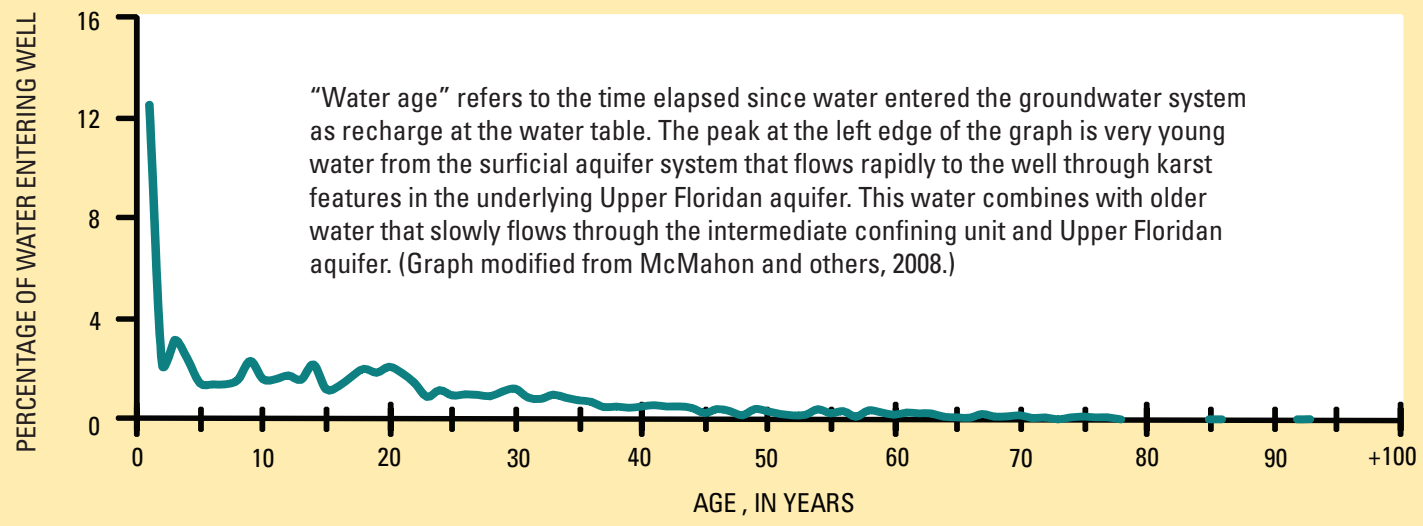

Figure 1. A groundwater flow model was used to simulate the mixture of water of different ages produced by the selected public-supply well in Temple Terrace, Florida.

radon-222 and stable isotopes of oxygen and hydrogen that are intermediate between the typical composition of water from the surficial aquifer system and that from the Upper Floridan aquifer. These findings suggest that the public-supply well produces a mixture of water from the two aquifers. Mixing calculations based on geochemical mass balance show that the water produced by the publicsupply well could consist of upwards of 50 percent water from the surficial aquifer mixed with water from the Upper Floridan aquifer.

Water from the surficial aquifer system appears to reach the public-supply well through the cavernous zone near the base of the open interval. Samples of water entering the supply well from this zone had a distinctly different chemis-

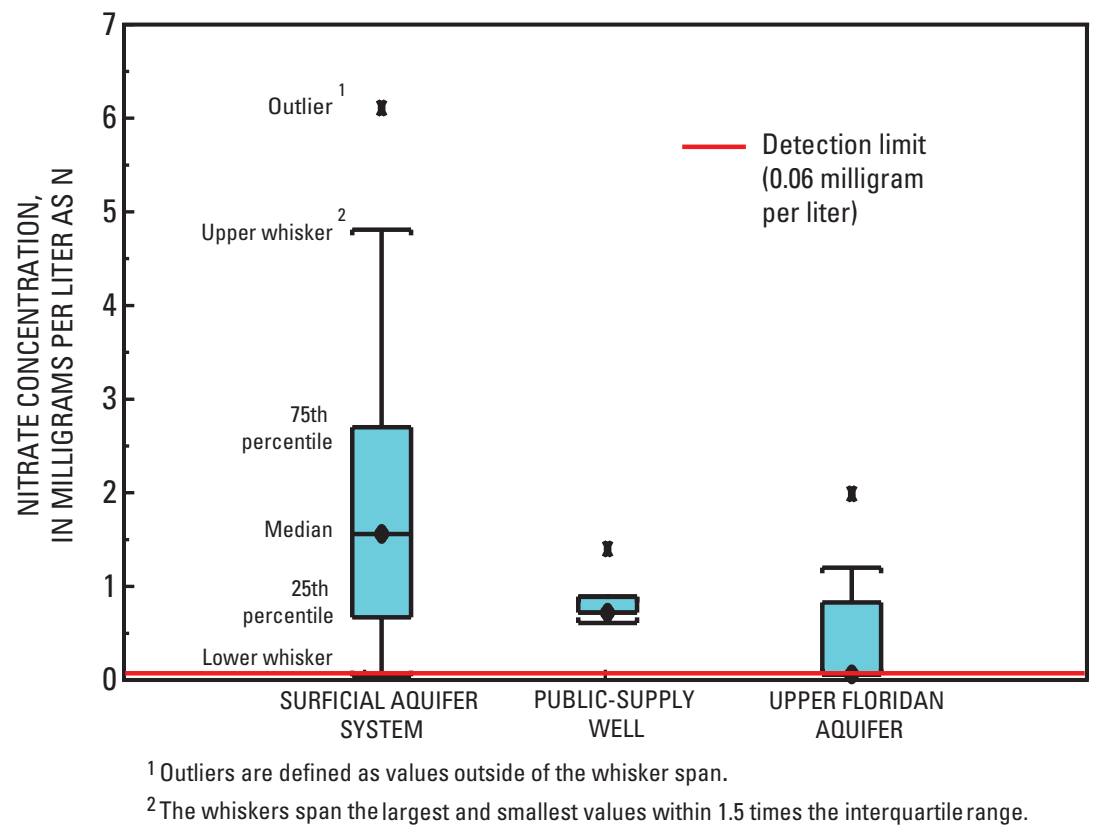

Figure 2. Concentrations of nitrate in the selected public-supply well are intermediate between those found in the Upper Floridan aquifer and the surficial aquifer system. try than water entering the well from a shallower zone in the Upper Floridan aquifer during nonpumping conditions. Specifically, water from the cavernous zone had higher concentrations of nitrate, radon-222, and trichloromethane (chloroform), as well as lower specific conductance, compared to water from the shallower depth interval sampled. To reach the public-supply well, water from the surficial aquifer system likely moves downward through breaches in the intermediate confining unit caused by sinkholes. The cavernous zone tapped at the bottom of the open interval of the selected public-supply well (and several other supply wells in the area) must be directly connected to one or more sinkholes and conduits.

\section{Natural Geochemical Processes in Aquifer Affect the Fate of Contaminants}

Geochemical conditions, such as oxygen content of groundwater, control whether specific contaminants are attenuated or mobilized in the subsurface. In the oxic conditions generally found in the surficial aquifer system (dissolved oxygen concentrations of at least $1 \mathrm{mg} / \mathrm{L}$ (milligram per liter)), the anthropogenic contaminant nitrate is stable and can be transported long distances. Thus, it is not surprising that elevated nitrate-N concentrations (maximum of $6.1 \mathrm{mg} / \mathrm{L}$ ) were found in the monitoring wells completed in the surficial aquifer system. However, in the "anoxic" conditions (dissolved oxygen concentrations less than 0.5 $\mathrm{mg} / \mathrm{L}$ ) typically present in monitoring wells of the intermediate confining unit and in the Upper Floridan aquifer, nitrate is naturally attenuated by a process known as denitrification, in which nitrate is converted to nitrogen gas. Because of this process, concentrations of nitrate in water from the Upper Floridan aquifer are generally low (less than the detection limit of $0.06 \mathrm{mg} / \mathrm{L}$ ).

In contrast to nitrate, the concentration of the natural contaminant radon-222 is not influenced by the oxygen content of the aquifers but is instead controlled by the geochemical makeup of the aquifer matrix and the process of radioactive decay. Radon-222 is one of the products formed by radioactive decay of the parent material uranium-238. In turn, radon-222 itself decays. Concentrations of radon were found to be highest in the surficial aquifer system and intermediate confining unit, where uranium- 238 was more concentrated in the aquifer matrix. As 
groundwater travels downward into the Upper Floridan aquifer, away from the higher concentrations of parent material, radon-222 concentrations generally decrease as the radon decays - from median concentrations of $2,440 \mathrm{pCi} / \mathrm{L}$ (picocuries per liter) in the surficial aquifer system to $2,100 \mathrm{pCi} / \mathrm{L}$ in the intermediate confining unit and $645 \mathrm{pCi} / \mathrm{L}$ in the Upper Floridan aquifer. The effect on human health of ingesting water with these concentrations of radon is unclear, because the U.S. Environmental Protection Agency (USEPA) has not finalized regulations setting a Maximum Contaminant Level (MCL) for radon in drinking water. All sampled waters had radon concentrations that exceed the proposed MCL of $300 \mathrm{pCi} / \mathrm{L}$ but were well below a proposed alternative MCL of 4,000 $\mathrm{pCi} / \mathrm{L}$ that factors in plans to address radon in indoor air (U.S. Environmental Protection Agency, 1999).

If the intermediate confining unit were intact throughout the Tampa area, natural attenuation - through the processes of denitrification and radioactive decay - would lessen the concentrations of nitrate and radon-222 reaching the public-supply well. These processes are circumvented, however, by the karst features such as sinkholes that breach the intermediate confining unit and serve as fast pathways to the well. Instead of traveling slowly through the aquifer matrix, young water from the surficial aquifer system may be shunted directly into a conduit, where it spends relatively little time before being captured and discharged by the supply well. Thus, attenuating reactions such as denitrification and radioactive decay may not progress as far in the cavernous zone as elsewhere in the Upper Floridan aquifer. Differences in reaction progress among the different parts of the Upper Floridan aquifer are likely exacerbated when local pumping centers further accelerate the movement of water in the cavernous zone. Because water produced by the public-supply well is a mixture of relatively young, oxygenated water from the cavernous zone and older, anoxic water from other parts of the Upper Floridan aquifer, contaminants such as nitrate and radon in this and other supply wells intersecting the cavernous zone are somewhat diluted relative to waters of the surficial aquifer system.

\section{Pumping of Public-Supply Well Enhances Vulnerability to Arsenic}

Arsenic concentrations in samples from the public-supply wellhead remained at or below $3.5 \mu \mathrm{g} / \mathrm{L}$ (micrograms per liter) throughout the study-below the MCL of $10 \mu \mathrm{g} / \mathrm{L}$. However, depth-dependent sampling while the public-supply well was being pumped showed that water entering the well from the cavernous zone near the base of the open interval contained arsenic and dissolved oxygen concentrations as high as $18.9 \mu \mathrm{g} / \mathrm{L}$ and $1.0 \mathrm{mg} / \mathrm{L}$, respectively. Surprisingly, during nonpumping conditions on the previous day, water from this same zone had a substantially lower arsenic concentration $(4.2 \mu \mathrm{g} / \mathrm{L})$ and a lower dissolved oxygen concentration $(0.8 \mathrm{mg} / \mathrm{L})$. This implies that movement of arsenic and dissolved oxygen to the public-supply well from the cavernous zone in the Upper Floridan aquifer is enhanced by pumping.

The movement of oxygenated water during pumping may actually liberate arsenic from the aquifer matrix. Arthur and others (2002) noted that arsenic was mobilized from the matrix of the Upper Floridan aquifer when oxic water was injected into an aquifer storage and recovery well field in Tampa. When the water was recovered from the Upper Floridan aquifer, it contained arsenic at concentrations more than 5 times the initial concentration in either the injected water or the native groundwater. One possible explanation for the higher arsenic concentrations during pumping is that the higher oxygen content of the groundwater in the cavernous zone (than elsewhere in the Upper Floridan aquifer) causes dissolution of arsenic associated with pyrite. Pyrite is a naturally occurring mineral the Upper Floridan aquifer that is most abundant in high-porosity zones (Price and Pichler, 2006).

\section{Protection Effort Implications}

\section{Public-supply wells that intersect solution features may benefit from a secondary area of protection. Efforts to} protect drinking-water supplies derived from groundwater generally rely on restricting activities within the area contributing recharge to a public-supply well. The State of Florida requires a primary protection zone within a radius of 500 feet around the well, where activities such as construction of new landfills or new aboveground or underground hazardous waste storage tanks are prohibited and other new installations, such as new domestic wastewater treatment facilities, must meet stringent performance standards. Communities are encouraged (but are not required) to define a secondary area of protection around the wellhead by using methods such as a time-of-travel calculation (Florida Department of Environmental Protection, 2008) to delineate

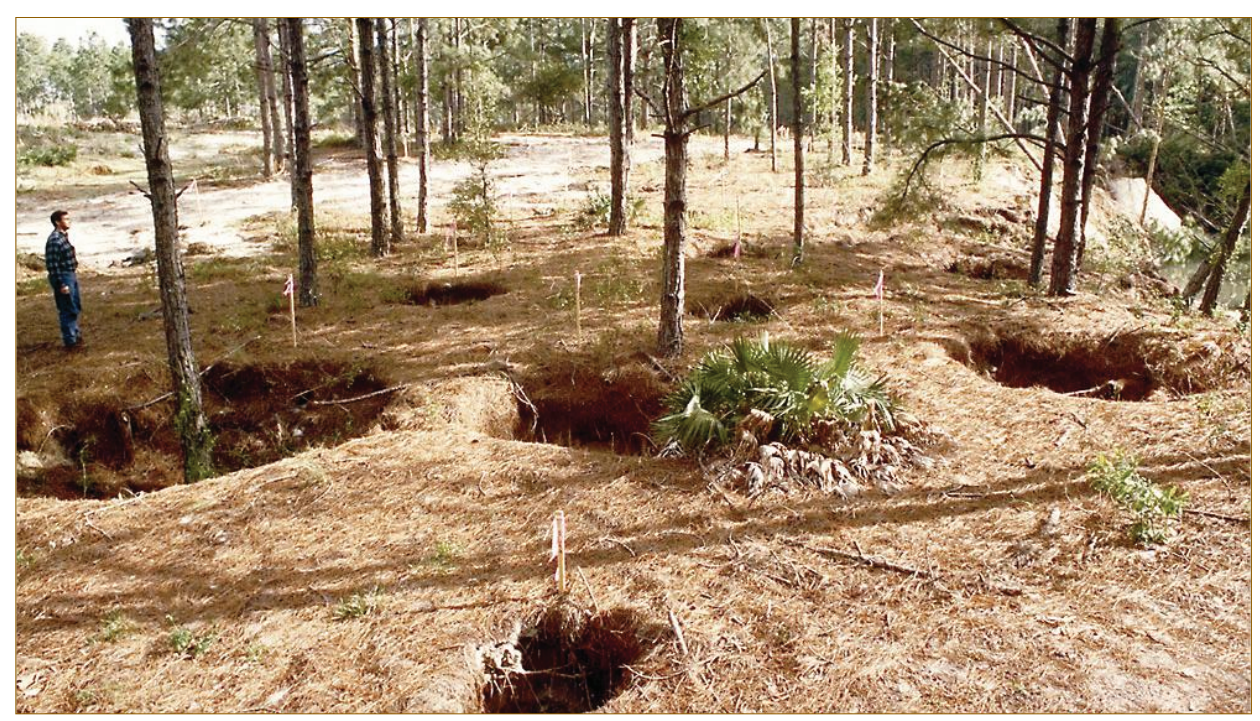

The sinkholes peppering this Florida forest are typical of karst topography that forms when underlying limestone partially dissolves. Other solution features (like the cavernous zone intersected by several wells in this study) may form along horizontal bedding planes and not be evident at land surface. (Photo by Ann Tihansky, U.S. Geological Survey.) 

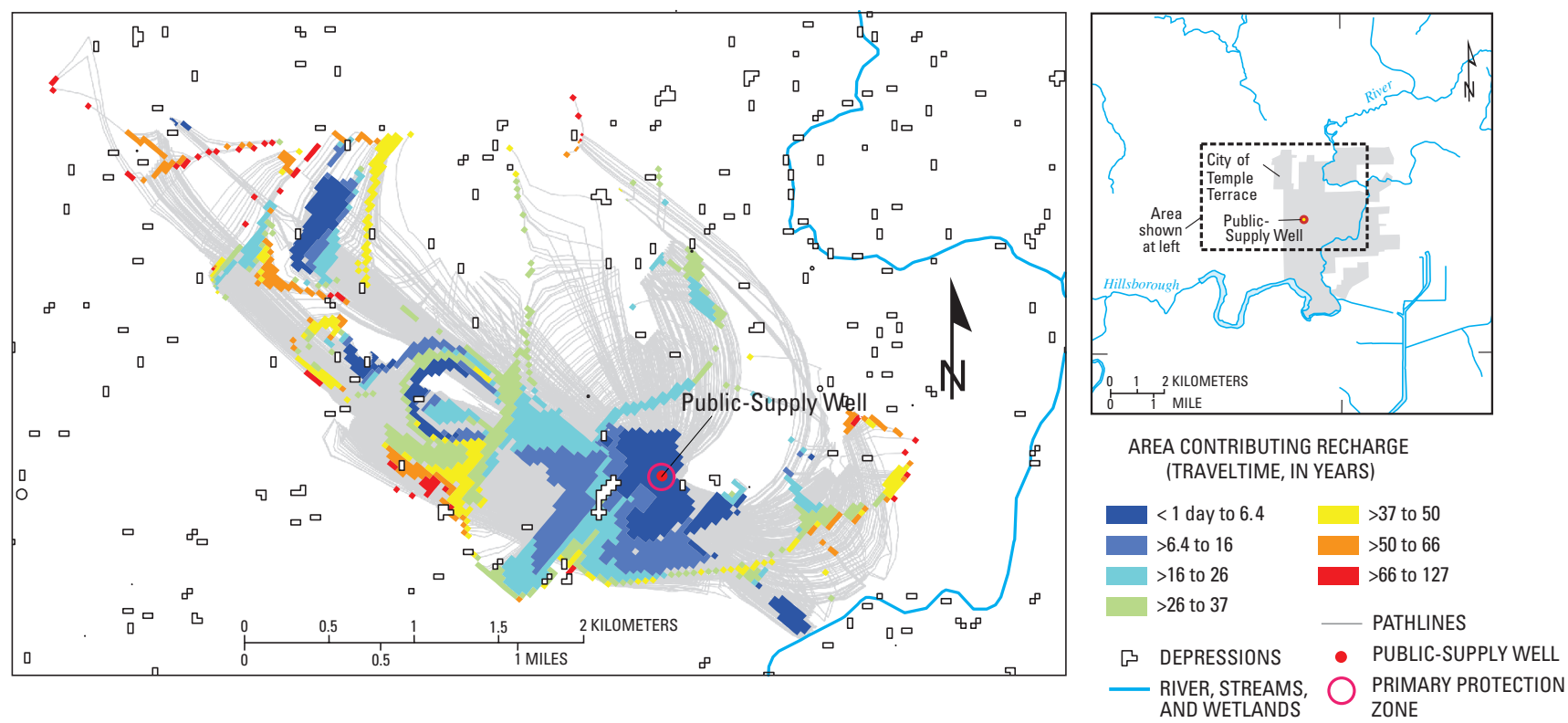

Figure 3. The colored zones on the map show the simulated area contributing recharge to a supply well selected for investigation in Temple Terrace, Florida. These zones indicate where much of the water that eventually reaches the well likely enters the groundwater system at the water table. The exact location of these zones cannot be defined with certainty due to lack of data regarding the location and interconnectedness of subsurface solution features. However, the simulated, noncontiguous pattern of recharge is realistic given that karst features allow water from the surficial aquifer system to short-circuit the intermediate confining unit and much of the Upper Floridan aquifer and travel to the supply well in unexpected ways. Restricting land-use activities in a 500 -foot radius around the well (the primary protection zone required by the State of Florida) protects only a small portion of the area contributing recharge that is associated with rapid traveltimes to the well.

the aquifer volume through which water will travel to the well within a certain amount of time. Figure 3 shows the simulated area contributing recharge to the selected public-supply well and associated times for water particles recharging the water table to travel to the well. Although some simulated areas associated with rapid traveltimes (less than 1 day to 6.4 years) are adjacent to the public-supply well, some are also more than 2 miles from the wellhead, owing to rapid traveltimes along flow paths that follow solution features in the Upper Floridan aquifer. Figure 3 demonstrates that, for wells intersecting solution features in the Upper Floridan aquifer, restricting activities only within a 500-foot radius around the well may not provide adequate protection or time to react if incidents of unexpected contamination (such as spills or leakage from chemical storage tanks) do occur. Wells that intersect solution features may warrant additional study to provide information upon which a more effective secondary area of protection can be based. For example, the traveltimes shown in figure 3 were estimated by use of a groundwater-flow model that took into account sinkhole locations and preferential flow along fractures and solution features, as well as average withdrawals and the interval of the aquifer tapped by the 76 other public-supply, industrial, or agricultural wells in the modeled area.

Similarity of public-supply well water to that of the surficial aquifer system is one measure of well vulnerability that could be used to prioritize protection efforts. Although water from the surficial aquifer system is recognized as being less desirable for use as drinking water than that of the Upper Floridan aquifer, in reality the surficial aquifer system probably makes up a notable proportion of the water produced by publicsupply wells in the Tampa area that are completed in the Upper Floridan aquifer and intersect a solution feature. Even though the open interval of the publicsupply well selected for study is more than 115 feet below land surface in an aquifer separated from the surficial aquifer system by a discontinuous confining layer, Katz and others (2007) determined that upwards of 50 percent of the water produced by the public-supply well may be very young water from the surficial aquifer system.

All public-supply wells in the area may not have this same level of vulnerability - many of the public-supply wells in the region have lower pumping rates and have open intervals that extend deeper into the Upper Floridan aquifer than the well studied. Thus, such wells may draw in proportionally less water from the surficial aquifer system than the selected well, and what they do draw in may be diluted by a larger proportion of old water from deeper in the Upper Floridan aquifer that predates anthropogenic influences. One way to evaluate the level of vulnerability of various public-supply wells in the region would be to determine the degree to which the water quality in these wells reflects that of the surficial aquifer system as described by Katz and others (2007). Such knowledge could be used to help prioritize monitoring and land-use planning efforts to protect the most vulnerable wells (Landon and others, 2006). If the suggested analysis shows that deeper public-supply wells are less vulnerable, water suppliers could consider deepening the most vulnerable wells and constructing new wells with longer and deeper open intervals to maximize in-well dilution.

Concentrations of contaminants produced by the public-supply well are strongly influenced by land-surface activities over the last decade. Nitrate concentrations in the public-supply well over time are a result of (1) the mixture of ages of water reaching the well 
combined with (2) changing nitrogen inputs at land surface over time (from sources such as application of inorganic fertilizer) and (3) denitrification rates in the intermediate confining unit and Upper Floridan aquifer. The effect of these three factors on long-term nitrate concentrations in the public-supply well was estimated by using the local-scale groundwater model. The simulated age distribution of water produced by the public-supply well (fig. 1) was used to determine the proportions of water that recharged in different years. Proportions of recharging water during a given year were then linked with the nitrate concentration in recharge during that year as estimated by McMahon and others (2008). Input nitrate concentrations were tracked as they moved through the geologic layers in the model. In the layers representing the oxic surficial aquifer system, nitrate concentrations were not adjusted. Once water particles entered the anoxic intermediate confining unit and Upper Floridan aquifer, probable minimum and maximum denitrification rates were applied to particles until they reached the public-supply well. The final calculated nitrate concentration at the public-supply well during a given year was the sum of nitrate concentrations of all water particles reaching the well that year, taking into account flow volumes represented by the particles. The calculated long-term nitrate concentrations in the selected public-supply well indicate a 1- to 10-year time lag between peak input concentrations in groundwater recharge and peak concentrations in the public-supply well. This short lag time reflects the large proportion of young water produced by the well and the strong influence that inputs at land surface within the last decade have on contaminant concentrations in water currently reaching the well. Future projections indicate that if fertilizer application rates in the urban area remain at current levels and land use remains fixed at the current proportion of 84 percent urban, then nitrate concentrations in the selected public-supply well will remain at about 1 to $3 \mathrm{mg} / \mathrm{L}$ in the future.

\section{Contacts}

Sandra Eberts, Team Leader (614) 430-7740, smeberts@usgs.gov

Christy Crandall, Groundwater Flow Modeling (850) 553-3674, crandall@usgs.gov

Brian Katz, Geochemistry (850) 553-3671, bkatz@usgs.gov

\section{References}

Arthur, J.D., Dabous, A.A., and Cowart, J.B., 2002, Mobilization of arsenic and other trace elements during aquifer storage and recovery, southwest Florida, in Aiken, G.R., and Kuniansky, E.L., eds., U.S. Geological Survey Artificial Recharge Workshop Proceedings: U.S. Geological Survey OpenFile Report 02-89, p. 47-50, accessed May 22, 2009, at http://water.usgs.gov/ ogw/pubs/ofr0289/

Crandall, C.A., 2007, Hydrogeologic setting and ground-water flow simulations of the Northern Tampa Bay Regional Study Area, Florida, section 5 of Paschke, S.S. ed., Hydrogeologic settings and ground-water flow simulations for regional studies of the transport of anthropogenic and natural contaminants to public-supply wellsStudies begun in 2001: U.S. Geological Survey Professional Paper 1737-A, sec. 5, accessed March 17, 2008, at http://pubs.usgs.gov/pp/2007/1737a

Crandall, C.A., Kauffman, L.J., Katz, B.G., Metz, P.A., McBride, W.S., and Berndt, M.P., in press, Simulations of groundwater flow and particle tracking analysis in the area contributing recharge to a public-supply well near Temple Terrace, Florida, 2002-05: U.S. Geological Survey Scientific Investigations Report 2008-5231, 53 p.

Florida Department of Environmental Protection, 2008, Wellhead protection: Accessed September 16, 2008, at http://www.dep.state.fl.us/water/ groundwater/wellhead.htm
Hamilton, P.A., Miller, T.L., and Myers, D.N., 2004, Water quality in the Nation's streams and aquifers - Overview of selected findings, 1991-2001: U.S. Geological Survey Circular 1265, $20 \mathrm{p}$.

Katz, B.G., Crandall, C.A., Metz, P.A., McBride, W.S., and Berndt, M.P., 2007, Chemical characteristics, water sources and pathways, and age distribution of ground water in the contributing area of a public-supply well near Tampa, Florida, 2002-05: U.S. Geological Survey Scientific Investigations Report 2007-5139, 85 p.

Landon, M.K., Eberts, S.M., Jurgens, B.C., Katz, B.G., Burow, K.R., Crandall, C.A., Brown, C.J., Starn, J.J., 2006, Knowledge of where and how contamination-susceptible water enters public-supply wells can be used to improve monitoring strategies and protection plans: Groundwater Protection Council Annual Forum 2006, Sept. 30-Oct. 4, 2006, Miami Beach, Fla., 15 p., accessed October 7, 2008, at http://oh.water.usgs.gov/tanc/ pubs/Landon_Eberts_CA-3521_gwpc_ paper_final_ss.pdf

McMahon, P.B., Böhlke, J.K., Kauffman, L.J., Kipp, K.L., Landon, M.K., Crandall, C.A., Burow, K.R., and Brown, C.J., 2008, Source and transport controls on the movement of nitrate to public supply wells in selected principal aquifers of the United States: Water Resources Research, v. 44, W04401, 17 p.

Price, R.E., and Pichler, Thomas, 2006, Abundance and mineralogical association of arsenic in the Suwannee Limestone (Florida)_-Implications for arsenic release during water-rock interaction: Chemical Geology, v. 228, p. 44-56.

U.S. Environmental Protection Agency, 1999, Proposed radon in drinking water rule: EPA 815-F-99-006, 6 p.

By Martha L. Jagucki, Brian G. Katz, Christy A. Crandall, and Sandra M. Eberts

For more information on the Transport of Anthropogenic and Natural Contaminants to Supply Wells (TANC) topical study, see http://oh.water.usgs.gov/tanc/NAWQATANC.htm 